\title{
Differences in Danish children's diet quality on weekdays $v$. weekend days
}

\author{
Berit W Rothausen ${ }^{1, *}$, Jeppe Matthiessen ${ }^{1}$, Camilla Hoppe ${ }^{1}$, Per B Brockhoff ${ }^{2}$, \\ Lene F Andersen ${ }^{3}$ and Inge Tetens ${ }^{1}$ \\ 'Division of Nutrition, National Food Institute, Technical University of Denmark, Mørkhøj Bygade 19, DK-2860 \\ Søborg, Denmark: ${ }^{2}$ Department of Informatics and Mathematical Modeling, Technical University of Denmark, \\ Kongens Lyngby, Denmark: ${ }^{3}$ Department of Nutrition, Institute of Basic Medical Sciences, University of Oslo, \\ Oslo, Norway
}

Submitted 1 December 2011: Final revision received 16 March 2012: Accepted 17 April 2012: First published online 25 May 2012

\begin{abstract}
Objective: To compare differences in children's diet quality on weekdays (MondayThursday), Fridays and weekend days.

Design: A representative cross-sectional study in which participants completed a $7 \mathrm{~d}$ pre-coded food record. Mean intakes of energy, macronutrients and selected food items (g/10 MJ) as well as energy density were compared between weekdays, Fridays and weekend days for each gender in three age groups (4-6, 7-10 and 11-14 years) using Tobit analysis to account for zero intakes.

Setting: The Danish National Survey of Dietary Habits and Physical Activity 2003-2008.

Subjects: Children ( $n$ 784; 49.9\% boys) aged $4-14$ years.

Results: For both genders in all age groups $(P<0 \cdot 05)$, energy intake was higher during weekends than on weekdays, and intakes of sugar-sweetened beverages and white bread were higher, whereas intake of rye bread was lower. This contributed to a higher percentage of energy from added sugars, a lower fibre content and a higher energy density on weekend days $v$. weekdays. In children aged 4-6 and 7-10 years, the diet on weekend days was also characterized by higher intakes of sweets and chocolate and lower intakes of fruit and vegetables. Overall, the diet on Fridays appeared as a mix of the diets on weekdays and weekend days.

Conclusions: Significant differences and distinct characteristic patterns were found in children's diet quality during weekdays, Fridays and weekend days. The present study suggests that in prevention of childhood overweight and obesity, more attention should be paid to the higher energy intake, especially from sugar-rich foods and beverages, on Fridays and weekend days.
\end{abstract}

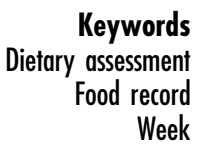

Dietary intake plays an important role in the prevention of chronic diseases ${ }^{(1,2)}$ and the adverse effects of children's unhealthy eating behaviours, in particular the increasing prevalence of childhood overweight and obesity, have become a significant public health challenge ${ }^{(3)}$. Unfavourable diets in childhood may have long-term implications, especially as tracking of overweight from childhood to adulthood occurs, and thereby increase the risk of subsequent morbidity and mortality ${ }^{(4,5)}$. The evidence of consistency in relation to dietary habits in children is limited and most studies report only poor to moderate stability over time, indicating that the diets of children are potentially modifiable ${ }^{(6)}$.

Compared with food-based dietary guidelines and nutritional recommendations, many children generally consume too little fruit and vegetables, fish and fibre, and too much of foods high in fat and sugar ${ }^{(7,8)}$. As improved nutrition is a key factor in promoting health, growth and development in children, there is an obvious need to address this issue.

It has been suggested that family factors and the nature of foods available at home, in schools and in fast-food establishments are some of the most significant determinants of the eating habits of children ${ }^{(9)}$. In this context, weekdays and weekend days differ in many ways, both structurally and culturally, which may influence dietary intake patterns, for example through more access to food and snacks, together with likely expectations of fewer restrictions on weekend days than during weekdays. Periods of holidays and summer vacations have been associated with increases in weight status in both children $^{(10)}$ and adults $^{(11)}$, and similar differences may apply on a smaller scale to weekends. 
Previous research in children has suggested that snacking and other daily eating patterns differ on weekdays compared with weekend days in a way that may have an impact on the overall diet quality on these days ${ }^{(12,13)}$. Moreover, Friday stands out as a weekday on which the diet may resemble both weekdays and weekend days in terms of diet quality. However, few studies have considered these issues of dietary intake. The objective of the present study was therefore to compare differences in diet quality on weekdays (Monday-Thursday), Fridays and weekend days in a simple random sample of Danish children.

\section{Methods}

\section{Sample}

Data for the present study were derived from the Danish National Survey of Dietary Habits and Physical Activity 2003-2008, which is a nationwide cross-sectional survey. The study population comprised a simple random sample of 4-14-year-old children, retrieved from the Central Office of Civil Registration. Participants received an invitation letter and were afterwards contacted by telephone. For the families who agreed to participate, written informed consent was obtained from a parent of each child prior to their participation. In comparison with census data from Statistics Denmark, the distribution of gender and age of the participants could be characterized as representative for the Danish population of children aged 4-14 years.

\section{Assessment of dietary intake}

Dietary intake was recorded every day for seven consecutive days in food records with pre-coded response categories, which included open answer options. Children and their parents were instructed in person by trained interviewers on how to complete the food records. The parents were responsible for completing the records and for deciding to what extent their children were capable of assisting. The food record was organized according to the typical Danish meal pattern (breakfast, lunch, dinner and in between meals). Each meal was divided into sections with headings such as beverages, bread, spreadable fats, meat and vegetables to make it easier to find and record the relevant foods, dishes and beverages. For food items not included in the pre-coded food record, the participants wrote the type of food and portion size eaten in open answer categories. The quantities of foods consumed were given in predefined household measures (cups, spoons, slices, etc.) or estimated from photographs in a picture book containing fourteen series of food photographs, each series showing four to six different portion sizes. As a supplement to the food record, participants also received a food recording booklet for the children to take to school or to other places outside their home on the days of assessment. Intakes of energy, nutrients and food items were calculated for each individual using the software system GIES version 0.995a (developed at the National Food Institute, Technical University of Denmark, Søborg, Denmark) and the Danish Food Composition Databank version 7 (www.foodcomp.dk). Validation of the method for children and adults is described elsewhere ${ }^{(14,15)}$.

Besides energy intake and macronutrients, a number of food items were selected to give an indication of the diet quality. The selection of variables was based on the work of Sepp et $a l^{(16)}$ and the Nordic Monitoring project ${ }^{(17)}$, which has shown that the intake of certain food groups explains a considerable part of the variation in the relative content of total fat, saturated fat, added sugars and dietary fibre in the diet. The intake of these food groups is therefore particularly useful in the assessment of overall nutritional quality of the diet. Energy density of the diet was calculated separately for (i) solid foods and liquids consumed as food (e.g. soups and yoghurt) and (ii) beverages, including both energy-containing and non-energy-containing beverages (e.g. milk/juice and water/tea, respectively) and presented as $\mathrm{kJ} / 100 \mathrm{~g}$. Furthermore, dietary intake based on the average intake during the week was compared with the nutritional recommendations for added sugars, saturated fat, fish and fruit and vegetables ${ }^{(18,19)}$.

\section{Definition of weekdays and weekend days}

Weekdays and weekend days were defined as Monday to Thursday and as Saturday and Sunday, respectively. Preliminary analysis showed that intakes on Friday differed from those on both Monday to Thursday and Saturday and Sunday. Therefore Friday was kept as a period of its own, instead of making a dichotomous weekday/weekend day variable.

\section{Weight status}

Information about the children's height and weight was obtained through a personal face-to-face interview with one of the parents, referred to as the 'responding parent', which was the mother in $87 \%$ of cases. Prevalence of overweight and obesity in the study sample was defined according to international age- and gender-specific BMI cut-off values for children and adolescents ${ }^{(20)}$ corresponding to BMI values of $\geq 25$ and $\geq 30 \mathrm{~kg} / \mathrm{m}^{2}$, respectively, for adults aged $\geq 18$ years.

\section{Parental education}

The educational level of the responding parent was defined in four categories: (i) basic school (10 years or less of total education); (ii) vocational education, upper secondary school (10-12 years); (iii) short higher education (13-15 years, primarily theoretical); and (iv) long higher education $(15+$ years, primarily theoretical).

\section{Definition of under-reporters and over-reporters} Prevalence of misreporters was assessed by evaluating the 95\% confidence limits of agreement between recorded 
energy intake and estimated BMR on the individual level. The Goldberg's cut-off 2 criterion was used ${ }^{(21)}$, which takes into account age- and gender-specific values for physical activity. Physical activity level values corresponding to light physical activity were used to define cut-off values for under-reporters and over-reporters, respectively ${ }^{(22)}$. Estimates of BMR were calculated from equations based on age, gender, height and weight ${ }^{(23)}$.

\section{Statistical analyses}

The main analyses were performed separately for the three age groups, 4-6 years, 7-10 years and 11-14, years due to the wide age range of children in the study population and associated different degree of parental influence on the diet and diet recording. Differences between gender regarding height, weight and BMI were analysed using Student's $t$ test, whereas differences between age groups regarding height, weight and BMI were analysed using one-way ANOVA and Tukey's post hoc test. Differences regarding parental education and weight status were assessed between gender and between age groups using the $\chi^{2}$ test and Fisher's exact test.

Differences in energy intake, macronutrient intake and energy density for weekdays $v$. weekend days, Fridays $v$. weekdays and Fridays $v$. weekend days were analysed using Student's $t$ test. For some of the food items, especially sausages, full-fat cheese, fries and fried potatoes and rye bread, a high percentage of the children (up to $79 \%$ within the three age groups) had zero intakes during the week. To account for zero intakes, these variables were compared between weekdays, Fridays and weekend days using Tobit regression analysis, which includes the zero observations in the analysis by combining the binary information of intake $v$. zero intake with the quantitative intake values for the non-zero cases. Mean values and standard deviations were used to describe the diet, because some of the medians were equal to or close to zero.

Data were analysed separately for boys and girls due to significant gender differences in dietary intake in the preliminary analyses. Since the dietary intake analyses included multiple tests, Bonferroni corrections with $k=3$ were performed. The unit $\mathrm{g} / 10 \mathrm{MJ}$ was used to take differences in total energy intake into account and to assess the quality of the diet, rather than absolute intakes. Data were analysed with the SPSS for Windows statistical software package version 19.0 (SPSS Statistics, Inc., Chicago, IL, USA) and the $\mathrm{R}$ statistical software version 2.13·2 (2009; R Development Core Team, http://www. r-project.org) with a significance level of $P<0 \cdot 05$.

\section{Results}

\section{Study population}

A total of 1294 children were invited to participate and 1006 (78\%) children accepted. After exclusion of incomplete dietary recordings, data from 784 (61\%) children with seven consecutive days of dietary recording and information about BMI and parental educational level were available for analysis. The group of excluded children ( $n$ 222) comprised 27\% 4-6-year-olds, 32\% 7-10-year-olds and 41\% 11-14-year-olds. Characteristics of the study population are presented for each age group in Table 1. Within each age group no gender differences were found regarding height, weight, BMI and parental education. Furthermore, no gender differences were observed with regard to weight status for the 7-10- and

Table 1 Characteristics of the study population: children aged 4-14 years, the Danish National Survey of Dietary Habits and Physical Activity 2003-2008

\begin{tabular}{|c|c|c|c|c|c|c|c|}
\hline & \multicolumn{2}{|c|}{$4-6$ years $(n 207)$} & \multicolumn{2}{|c|}{$7-10$ years $(n 287)$} & \multicolumn{2}{|c|}{$11-14$ years $(n$ 290) } & \multirow[b]{2}{*}{$P$ value* } \\
\hline & Mean & SD & Mean & SD & Mean & SD & \\
\hline Gender, boys/girls (\%) & \multicolumn{2}{|c|}{$50 / 50$} & \multicolumn{2}{|c|}{$53 / 47$} & \multicolumn{2}{|c|}{$47 / 53$} & 0.303 \\
\hline Height $(\mathrm{cm})$ & $118^{\mathrm{c}}$ & 9 & $139^{b}$ & 9 & $161^{\mathrm{a}}$ & 10 & $<0.001$ \\
\hline Weight (kg) & $22 \cdot 0^{\mathrm{C}}$ & $4 \cdot 3$ & $32 \cdot 8^{\mathrm{b}}$ & $7 \cdot 5$ & $49 \cdot 9^{a}$ & $10 \cdot 7$ & $<0.001$ \\
\hline BMI $\left(\mathrm{kg} / \mathrm{m}^{2}\right)$ & $15 \cdot 6^{\mathrm{c}}$ & $1 \cdot 9$ & $16 \cdot 8^{b}$ & $2 \cdot 6$ & $19 \cdot 1^{a}$ & $3 \cdot 0$ & $<0.001$ \\
\hline \multicolumn{8}{|l|}{ Weight statust (\%) } \\
\hline Normal weight, boys/girls & \multirow{2}{*}{\multicolumn{2}{|c|}{$\begin{array}{l}91 \cdot 3 / 80 \cdot 6 \\
8 \cdot 7 / 15 \cdot 5\end{array}$}} & \multicolumn{2}{|c|}{$82 \cdot 2 / 81 \cdot 5$} & \multicolumn{2}{|c|}{$79 \cdot 3 / 82 \cdot 6$} & $0 \cdot 074 / 0 \cdot 981$ \\
\hline Overweight, boys/girls & & & \multicolumn{2}{|c|}{$13 \cdot 8 / 14 \cdot 1$} & \multicolumn{2}{|c|}{$17 \cdot 8 / 14 \cdot 2$} & \\
\hline Obese, boys/girls & \multicolumn{2}{|c|}{$0 / 3 \cdot 9$} & & & & & \\
\hline \multicolumn{8}{|l|}{ Parental educationł (\%) } \\
\hline Basic school & \multicolumn{2}{|c|}{$\begin{array}{r}8 \cdot 7 \\
41 \cdot 5\end{array}$} & \multicolumn{2}{|c|}{$8 \cdot 7$} & \multicolumn{2}{|c|}{$11 \cdot 7$} & $0 \cdot 117$ \\
\hline Vocational education & & & & & & & \\
\hline Short higher education & \multicolumn{2}{|c|}{$8 \cdot 2$} & \multicolumn{2}{|c|}{$10 \cdot 1$} & \multicolumn{2}{|c|}{$\begin{array}{l}4<\cdot 4 \\
14 \cdot 5\end{array}$} & \\
\hline Long higher education & \multicolumn{2}{|c|}{$41 \cdot 5$} & \multicolumn{2}{|c|}{$37 \cdot 3$} & \multicolumn{2}{|c|}{$31 \cdot 4$} & \\
\hline
\end{tabular}

${ }^{a, b, c}$ Mean values within a row with unlike superscript letters were significantly different between age groups $(P<0 \cdot 001)$.

*Differences between age groups tested using the $\chi^{2}$ test for gender distribution and parental education, by one-way ANOVA for height, weight and BMI, and by Fisher's exact test for weight status.

+Weight status according to international cut off values ${ }^{(20)}$. Weight status differed significantly between genders in the $4-6$-year-old children $(P=0 \cdot 034)$, but not in the $7-10$-year-olds $(P=0.975)$ or in the $11-14$-year-olds $(P=0.705)$.

$\ddagger$ Parental educational level: basic school $=10$ years or less of total education; vocational education, upper secondary school $=10-12$ years; short higher education $=13-15$ years (primarily theoretical); long higher education $=15+$ years (primarily theoretical). 
Table 2 Dietary content by gender on weekdays (Monday-Thursday), Fridays and weekend days (Saturday and Sunday): 4-6-year-old children, the Danish National Survey of Dietary Habits and Physical Activity 2003-2008

\begin{tabular}{|c|c|c|c|c|c|c|c|c|c|c|c|c|}
\hline & \multicolumn{6}{|c|}{ Boys, $4-6$ years $(n 104)$} & \multicolumn{6}{|c|}{ Girls, 4-6 years $(n 103)$} \\
\hline & \multicolumn{2}{|c|}{ Weekdays } & \multicolumn{2}{|c|}{ Friday } & \multicolumn{2}{|c|}{ Weekend days } & \multicolumn{2}{|c|}{ Weekdays } & \multicolumn{2}{|c|}{ Friday } & \multicolumn{2}{|c|}{ Weekend days } \\
\hline & Mean & SD & Mean & SD & Mean & SD & Mean & SD & Mean & SD & Mean & SD \\
\hline \multicolumn{13}{|l|}{ Energy and nutrients } \\
\hline Energy $(\mathrm{MJ} / \mathrm{d})$ & $7 \cdot 5^{\mathrm{b}}$ & $1 \cdot 8$ & $8 \cdot 3^{a}$ & $2 \cdot 6$ & $8 \cdot 4^{\mathrm{a}}$ & $2 \cdot 7$ & $6 \cdot 6^{\mathrm{b}}$ & $1 \cdot 4$ & $7 \cdot 2^{a}$ & $2 \cdot 1$ & $7 \cdot 4^{a}$ & $1 \cdot 7$ \\
\hline Total fat $(E \%)$ & $33^{b}$ & 5 & $34^{a, b}$ & 7 & $35^{\mathrm{a}}$ & 6 & $34^{\mathrm{a}}$ & 5 & $32^{\mathrm{b}}$ & 7 & $35^{a}$ & 6 \\
\hline SFA (E\%) & 14 & 3 & 14 & 3 & 15 & 3 & 15 & 3 & 14 & 3 & 15 & 3 \\
\hline MUFA (E\%) & $11^{\mathrm{b}}$ & 2 & $12^{a, b}$ & 3 & $12^{\mathrm{a}}$ & 2 & $11^{\mathrm{a}}$ & 2 & $11^{\mathrm{b}}$ & 3 & $12^{\mathrm{a}}$ & 3 \\
\hline PUFA (E\%) & 5 & 1 & 5 & 1 & 5 & 1 & $5^{\mathrm{a}}$ & 1 & $4^{b}$ & 1 & $5^{\mathrm{a}}$ & 1 \\
\hline Carbohydrates (E\%) & 52 & 5 & 52 & 7 & 51 & 6 & $51^{\mathrm{b}}$ & 5 & $54^{\mathrm{a}}$ & 7 & $52^{\mathrm{b}}$ & 6 \\
\hline Added sugars (E\%) & $9^{b}$ & 5 & $14^{\mathrm{a}}$ & 8 & $13^{a}$ & 6 & $10^{\mathrm{b}}$ & 4 & $15^{\mathrm{a}}$ & 8 & $14^{\mathrm{a}}$ & 5 \\
\hline Fibre $(g / 10 \mathrm{MJ})$ & $25^{\mathrm{a}}$ & 6 & $22^{\mathrm{b}}$ & 8 & $20^{\mathrm{C}}$ & 6 & $25^{\mathrm{a}}$ & 6 & $21^{\mathrm{b}}$ & 7 & $19^{c}$ & 5 \\
\hline Protein (E\%) & $15^{\mathrm{a}}$ & 2 & $14^{\mathrm{b}}$ & 3 & $14^{\mathrm{b}}$ & 3 & $15^{\mathrm{a}}$ & 2 & $14^{\mathrm{b}}$ & 3 & $13^{\mathrm{C}}$ & 2 \\
\hline \multicolumn{13}{|l|}{ Foods (g/10 MJ) } \\
\hline Vegetables & $174^{\mathrm{a}}$ & 104 & $144^{a, b}$ & 139 & $133^{\mathrm{b}}$ & 114 & $178^{\mathrm{a}}$ & 94 & $141^{\mathrm{a}, \mathrm{b}}$ & 165 & $129^{b}$ & 90 \\
\hline Fruit & $276^{a}$ & 163 & $255^{a, b}$ & 262 & $189^{\mathrm{b}}$ & 171 & $273^{a}$ & 164 & $218^{a, b}$ & 184 & $205^{\mathrm{b}}$ & 198 \\
\hline Fish & $18^{a}$ & 21 & $14^{\mathrm{b}}$ & 33 & $18^{a, b}$ & 27 & $19^{\mathrm{a}}$ & 23 & $14^{\mathrm{b}}$ & 42 & $14^{\mathrm{a}, \mathrm{b}}$ & 2 \\
\hline Rye bread & $101^{a}$ & 49 & $83^{\mathrm{b}}$ & 58 & $62^{\mathrm{c}}$ & 46 & $86^{a}$ & 46 & $86^{\mathrm{a}}$ & 63 & $55^{\mathrm{b}}$ & 41 \\
\hline White bread & $46^{\mathrm{b}}$ & 40 & $38^{\mathrm{c}}$ & 50 & $69^{a}$ & 53 & $44^{a}$ & 40 & $49^{a}$ & 64 & $69^{\mathrm{b}}$ & 47 \\
\hline Butter on bread & 14 & 14 & 12 & 17 & 15 & 15 & 16 & 15 & 16 & 15 & 18 & 13 \\
\hline Full-fat cheese & 4 & 8 & 6 & 13 & 4 & 10 & 6 & 11 & 5 & 13 & 4 & 10 \\
\hline French fried potatoes & 11 & 21 & 22 & 44 & 19 & 34 & $18^{\mathrm{a}}$ & 27 & $18^{\mathrm{b}}$ & 44 & $29^{a}$ & 44 \\
\hline Sausages & 6 & 14 & 11 & 38 & 12 & 28 & $11^{a}$ & 21 & $7^{\mathrm{b}}$ & 31 & $11^{\mathrm{a}, \mathrm{b}}$ & 35 \\
\hline Sweets \& chocolate & $11^{\mathrm{b}}$ & 14 & $38^{a}$ & 44 & $28^{a}$ & 31 & $15^{\mathrm{c}}$ & 15 & $55^{\mathrm{a}}$ & 52 & $29^{b}$ & 27 \\
\hline Cakes \& biscuits & 33 & 39 & 46 & 77 & 46 & 50 & $29^{\mathrm{b}}$ & 37 & $34^{\mathrm{b}}$ & 60 & $50^{\mathrm{a}}$ & 49 \\
\hline SSB & $183^{\mathrm{b}}$ & 234 & $273^{a, b}$ & 350 & $274^{\mathrm{a}}$ & 245 & $154^{\mathrm{b}}$ & 184 & $274^{a, b}$ & 330 & $259^{\mathrm{a}}$ & 219 \\
\hline \multicolumn{13}{|l|}{ Energy density (kJ/100 g) } \\
\hline Energy density, foods & $704^{\mathrm{b}}$ & 127 & $794^{\mathrm{a}}$ & 220 & $844^{\mathrm{a}}$ & 197 & $712^{b}$ & 140 & $826^{a}$ & 229 & $864^{a}$ & 204 \\
\hline Energy density, beverages & $100^{b}$ & 42 & $104^{\mathrm{b}}$ & 52 & $121^{\mathrm{a}}$ & 48 & $112^{\mathrm{b}}$ & 49 & $117^{\mathrm{b}}$ & 53 & $131^{\mathrm{a}}$ & 49 \\
\hline
\end{tabular}

$\mathrm{E} \%$, percentage of energy intake; SSB, sugar-sweetened beverages.

a,b,c For each gender group, mean values within a row with unlike superscript letters were significantly different $(P<0 \cdot 05)$.

11-14-year-old children, but there were more overweight and obese girls than boys in the 4-6-year-old children $(P=0 \cdot 034)$. Height, weight and BMI were all significantly different between age groups $(P<0 \cdot 001)$, whereas there were no significant differences between age groups regarding gender distribution, weight status and parental education. The prevalence of identified under-reporters was $1 \cdot 0 \%$ in the 4-6-year-olds, $3 \cdot 8 \%$ in the $7-10$-year-olds and $16.6 \%$ in the $11-14$-year-olds. The number of under-reporters did not differ between genders.

Based on the average intake during the week, boys had a significantly higher total energy intake than girls in all three age groups (4-6 years: boys $7 \cdot 87(\mathrm{sD} 1 \cdot 87) \mathrm{MJ} / \mathrm{d}$ $v$. girls 6.91 (SD 1.34$) \mathrm{MJ} / \mathrm{d}, P<0.001 ; 7-10$ years: boys 8.79 (sD 1.94$) \mathrm{MJ} / \mathrm{d} v$. girls $8.19(\mathrm{sD} 2.03) \mathrm{MJ} / \mathrm{d}, P=0.01$; 11-14 years: boys $9.57(\mathrm{sD} 2 \cdot 83) \mathrm{MJ} / \mathrm{d} v$. girls $7 \cdot 74$ (sD 1.99$) \mathrm{MJ} / \mathrm{d}, P<0 \cdot 001$ ).

A large proportion of the children did not meet the nutritional recommendations of keeping the percentage of energy from added sugars below 10\% (66\% of the children) and the percentage of energy from saturated fat below $10 \%(96 \% \text { of the children })^{(18)}$. A total of $89 \%$ of the children did not reach the recommended intake of fish of at least $200 \mathrm{~g} /$ week, and the recommended intake of fruit and vegetables was not met by $66 \%$ of the 4-10-year-old children (recommended intake of $400 \mathrm{~g} / \mathrm{d}$ ) and by $91 \%$ of the 11-14-year-olds (recommended intake of $600 \mathrm{~g} / \mathrm{d})^{(19)}$.

\section{Food and nutrient intakes}

Mean intakes of energy, macronutrients, selected food items and energy density of the diet on weekdays, Fridays and weekend days are presented for each age group in Tables 2-4. The following results were all statistically significant at a significance level of $P<0 \cdot 05$.

\section{Weekdays v. weekend days}

For both boys and girls in all three age groups, energy intake was consistently higher on weekend days than on weekdays. Furthermore, the percentage of energy from added sugars was higher, whereas the fibre content and the percentage of energy from protein were lower on weekend days compared with weekdays. The diet also contained a higher amount of sugar-sweetened beverages (SSB) and white bread, and a lower amount of rye bread on weekend days $v$. weekdays. In addition, the energy density of foods as well as of beverages was higher on weekend days than on weekdays. Boys and girls aged 4-6 and 7-10 years also had higher intakes of sweets and chocolate and lower intakes of fruit and vegetables on weekend days compared with weekdays. 
Table 3 Dietary content by gender on weekdays (Monday-Thursday), Fridays and weekend days (Saturday and Sunday): 7-10-year-old children, the Danish National Survey of Dietary Habits and Physical Activity 2003-2008

\begin{tabular}{|c|c|c|c|c|c|c|c|c|c|c|c|c|}
\hline & \multicolumn{6}{|c|}{ Boys, $7-10$ years $(n 152)$} & \multicolumn{6}{|c|}{ Girls, $7-10$ years $(n 135)$} \\
\hline & \multicolumn{2}{|c|}{ Weekdays } & \multicolumn{2}{|c|}{ Friday } & \multicolumn{2}{|c|}{ Weekend days } & \multicolumn{2}{|c|}{ Weekdays } & \multicolumn{2}{|c|}{ Friday } & \multicolumn{2}{|c|}{ Weekend days } \\
\hline & Mean & SD & Mean & SD & Mean & SD & Mean & SD & Mean & SD & Mean & SD \\
\hline \multicolumn{13}{|l|}{ Energy and nutrients } \\
\hline Energy $(\mathrm{MJ} / \mathrm{d})$ & $8 \cdot 4^{c}$ & 1.9 & $9 \cdot 8^{a}$ & $3 \cdot 3$ & $9 \cdot 0^{b}$ & $2 \cdot 7$ & $7 \cdot 8^{b}$ & $2 \cdot 4$ & $9 \cdot 0^{\mathrm{a}}$ & $2 \cdot 9$ & $8 \cdot 6^{\mathrm{a}}$ & $2 \cdot 3$ \\
\hline Total fat (E\%) & $33^{\mathrm{b}}$ & 5 & $32^{b}$ & 7 & $34^{\mathrm{a}}$ & 6 & 33 & 5 & 32 & 6 & 33 & 6 \\
\hline SFA (E\%) & $14^{\mathrm{a}, \mathrm{b}}$ & 3 & $13^{\mathrm{b}}$ & 4 & $14^{\mathrm{a}}$ & 3 & $14^{\mathrm{a}}$ & 3 & $13^{\mathrm{b}}$ & 3 & $14^{\mathrm{a}, \mathrm{b}}$ & 3 \\
\hline MUFA (E\%) & $11^{\mathrm{b}}$ & 2 & $11^{\mathrm{b}}$ & 3 & $12^{\mathrm{a}}$ & 3 & $11^{a, b}$ & 2 & $11^{\mathrm{b}}$ & 3 & $11^{\mathrm{a}}$ & 2 \\
\hline PUFA (E\%) & 5 & 1 & 5 & 2 & 5 & 1 & 5 & 1 & 5 & 1 & 5 & 1 \\
\hline Carbohydrates (E\%) & $52^{\mathrm{b}}$ & 6 & $55^{\mathrm{a}}$ & 7 & $52^{\mathrm{b}}$ & 7 & $52^{\mathrm{b}}$ & 5 & $55^{\mathrm{a}}$ & 7 & $53^{a, b}$ & 6 \\
\hline Added sugars (E\%) & $11^{\mathrm{b}}$ & 5 & $15^{\mathrm{a}}$ & 8 & $15^{\mathrm{a}}$ & 7 & $10^{\mathrm{b}}$ & 4 & $16^{\mathrm{a}}$ & 8 & $16^{\mathrm{a}}$ & 7 \\
\hline Fibre $(g / 10 \mathrm{MJ})$ & $23^{a}$ & 7 & $21^{\mathrm{b}}$ & 8 & $18^{\mathrm{C}}$ & 6 & $24^{a}$ & 6 & $21^{\mathrm{b}}$ & 7 & $18^{\mathrm{C}}$ & 5 \\
\hline Protein (E\%) & $15^{a}$ & 2 & $14^{\mathrm{b}}$ & 3 & $14^{\mathrm{b}}$ & 3 & $15^{a}$ & 2 & $13^{\mathrm{b}}$ & 3 & $13^{\mathrm{b}}$ & 3 \\
\hline \multicolumn{13}{|l|}{ Foods (g/10 MJ) } \\
\hline Vegetables & $167^{\mathrm{a}}$ & 103 & $154^{\mathrm{a}, \mathrm{b}}$ & 138 & $130^{\mathrm{b}}$ & 118 & $180^{\mathrm{a}}$ & 117 & $173^{\mathrm{a}}$ & 137 & $118^{\mathrm{b}}$ & 103 \\
\hline Fruit & $260^{\mathrm{a}}$ & 204 & $197^{\mathrm{b}}$ & 235 & $157^{\mathrm{b}}$ & 151 & $274^{\mathrm{a}}$ & 200 & $215^{\mathrm{b}}$ & 221 & $184^{\mathrm{b}}$ & 173 \\
\hline Fish & 13 & 17 & 16 & 44 & 19 & 39 & 12 & 17 & 17 & 47 & 14 & 22 \\
\hline Rye bread & $72^{a}$ & 55 & $60^{\mathrm{b}}$ & 64 & $46^{\mathrm{b}}$ & 45 & $73^{a}$ & 50 & $60^{\mathrm{b}}$ & 58 & $44^{\mathrm{b}}$ & 42 \\
\hline White bread & $54^{\mathrm{b}}$ & 48 & $57^{\mathrm{b}}$ & 72 & $78^{\mathrm{a}}$ & 62 & $61^{\mathrm{b}}$ & 47 & $56^{\mathrm{b}}$ & 61 & $77^{a}$ & 48 \\
\hline Butter on bread & 10 & 11 & 9 & 12 & 12 & 13 & 12 & 11 & 10 & 12 & 12 & 12 \\
\hline Full-fat cheese & $5^{\mathrm{a}}$ & 10 & $3^{\mathrm{b}}$ & 10 & $6^{\mathrm{a}}$ & 12 & $3^{\mathrm{a}}$ & 7 & $3^{\mathrm{b}}$ & 10 & $4^{a, b}$ & 11 \\
\hline French fried potatoes & 18 & 28 & 23 & 52 & 27 & 43 & $15^{a, b}$ & 23 & $16^{\mathrm{b}}$ & 45 & $21^{\mathrm{a}}$ & 35 \\
\hline Sausages & $6^{\mathrm{a}, \mathrm{b}}$ & 15 & $8^{\mathrm{b}}$ & 33 & $13^{\mathrm{a}}$ & 36 & 5 & 14 & 6 & 24 & 9 & 23 \\
\hline Sweets \& chocolate & $13^{\mathrm{C}}$ & 16 & $43^{a}$ & 45 & $26^{\mathrm{b}}$ & 28 & $18^{b}$ & 23 & $46^{\mathrm{a}}$ & 45 & $33^{a}$ & 37 \\
\hline Cakes \& biscuits & $30^{a, b}$ & 38 & $35^{\mathrm{b}}$ & 63 & $45^{\mathrm{a}}$ & 53 & 35 & 39 & 46 & 75 & 53 & 64 \\
\hline SSB & $242^{b}$ & 297 & $348^{a, b}$ & 371 & $397^{a}$ & 357 & $175^{\mathrm{b}}$ & 183 & $335^{\mathrm{a}}$ & 387 & $378^{a}$ & 307 \\
\hline \multicolumn{13}{|l|}{ Energy density $(\mathrm{kJ} / 100 \mathrm{~g})$} \\
\hline Energy density, foods & $727^{b}$ & 149 & $841^{a}$ & 223 & $879^{a}$ & 191 & $713^{\mathrm{c}}$ & 152 & $804^{\mathrm{b}}$ & 215 & $859^{a}$ & 182 \\
\hline Energy density, beverages & $102^{\mathrm{b}}$ & 48 & $108^{b}$ & 60 & $116^{\mathrm{a}}$ & 52 & $100^{\mathrm{b}}$ & 47 & $103^{\mathrm{b}}$ & 56 & $122^{\mathrm{a}}$ & 55 \\
\hline
\end{tabular}

$\mathrm{E} \%$, percentage of energy intake; SSB, sugar-sweetened beverages.

${ }_{a, b, c}$ For each gender group, mean values within a row with unlike superscript letters were significantly different $(P<0.05)$.

\section{Fridays v. weekdays}

Energy intake was higher on Fridays than on weekdays for both boys and girls in all three age groups. Differences that applied to all groups also included a higher percentage of energy from added sugars, a lower percentage of energy from protein and a lower fibre content of the diet on Fridays than on weekdays. In addition, the intake of fruit was lower for the 4-6-year-olds and the 11-14-year-old girls, and the intake of rye bread was lower for all groups except for the 4-6-year-olds and the 11-14-year-old girls. The diet contained significantly higher amounts of sweets and chocolate on Fridays than on weekdays for all groups, although this was not significant for the 11-14-year-olds. The energy density of foods was higher on Fridays than on weekdays for all age and gender groups, and the 11-14-year-old girls also had a higher energy density of beverages on Fridays compared with weekdays.

\section{Fridays v. weekend days}

Energy intake did not differ significantly between Fridays and weekend days, except for the 7-10-year-old boys, who had a higher energy intake on Fridays than on weekend days. For both boys and girls in all three age groups intake of white bread was lower on Fridays than on weekend days. The fibre content of the diet was higher on Fridays compared with weekend days, although this was not significant for the 11-14-year-old boys, whereas intake of cakes and biscuits was lower for all groups, except for the 4-6-year-old boys and the 7-10-year-old girls. The energy density of foods was lower on Fridays than on weekend days in the 7-10-yearold girls, whereas the energy density of beverages was lower in the 4-6-year-olds and 7-10-year-old girls.

\section{Discussion}

Results from the present study showed that there were significant, distinct differences and characteristic patterns in the children's diet quality during weekdays, Fridays and weekend days. Results of the present study indicate that quality of the diet consumed during weekend days was lower than on weekdays, whereas the diet quality on Fridays appeared to be at an intermediate level. Furthermore, average energy intake and energy density were consistently higher on weekend days than on weekdays and intermediate on Fridays. The tendency of increasing energy density from weekdays to weekend days further supports the finding of decreasing diet quality from weekdays to weekend days, because higher energy density has previously has been associated with lower 
Table 4 Dietary content by gender on weekdays (Monday-Thursday), Fridays and weekend days (Saturday and Sunday): 11-14-year-old children: the Danish National Survey of Dietary Habits and Physical Activity 2003-2008

\begin{tabular}{|c|c|c|c|c|c|c|c|c|c|c|c|c|}
\hline & \multicolumn{6}{|c|}{ Boys, $11-14$ years $(n 135)$} & \multicolumn{6}{|c|}{ Girls, $11-14$ years $(n 155)$} \\
\hline & \multicolumn{2}{|c|}{ Weekdays } & \multicolumn{2}{|c|}{ Friday } & \multicolumn{2}{|c|}{ Weekend days } & \multicolumn{2}{|c|}{ Weekdays } & \multicolumn{2}{|c|}{ Friday } & \multicolumn{2}{|c|}{ Weekend days } \\
\hline & Mean & SD & Mean & SD & Mean & SD & Mean & SD & Mean & SD & Mean & SD \\
\hline \multicolumn{13}{|l|}{ Energy and nutrients } \\
\hline Energy $(\mathrm{MJ} / \mathrm{d})$ & $9 \cdot 0^{\mathrm{b}}$ & $2 \cdot 8$ & $10 \cdot 5^{a}$ & $4 \cdot 6$ & $10 \cdot 3^{a}$ & $3 \cdot 8$ & $7 \cdot 4^{b}$ & $2 \cdot 0$ & $8 \cdot 1^{a}$ & $3 \cdot 4$ & $8 \cdot 2^{a}$ & $2 \cdot 5$ \\
\hline Total fat (E\%) & 33 & 6 & 32 & 8 & 34 & 7 & 31 & 5 & 31 & 9 & 32 & 6 \\
\hline SFA (E\%) & 14 & 3 & 14 & 4 & 14 & 3 & 13 & 2 & 13 & 4 & 14 & 3 \\
\hline MUFA (E\%) & 11 & 2 & 11 & 3 & 12 & 3 & 11 & 2 & 11 & 4 & 11 & 3 \\
\hline PUFA (E\%) & $5^{\mathrm{a}}$ & 1 & $5^{b}$ & 2 & $5^{a, b}$ & 1 & 5 & 1 & 5 & 1 & 4 & 1 \\
\hline Carbohydrates (E\%) & $52^{b}$ & 6 & $54^{\mathrm{a}}$ & 9 & $52^{\mathrm{a}, \mathrm{b}}$ & 7 & 54 & 6 & 55 & 9 & 54 & 7 \\
\hline Added sugars (E\%) & $11^{\mathrm{b}}$ & 6 & $15^{\mathrm{a}}$ & 10 & $14^{\mathrm{a}}$ & 8 & $11^{\mathrm{b}}$ & 5 & $14^{\mathrm{a}}$ & 9 & $15^{\mathrm{a}}$ & 7 \\
\hline Fibre $(\mathrm{g} / 10 \mathrm{MJ})$ & $23^{a}$ & 7 & $20^{\mathrm{b}}$ & 9 & $19^{b}$ & 6 & $23^{a}$ & 7 & $21^{\mathrm{b}}$ & 8 & $18^{\mathrm{c}}$ & 6 \\
\hline Protein (E\%) & $15^{\mathrm{a}}$ & 3 & $14^{\mathrm{b}}$ & 3 & $14^{\mathrm{b}}$ & 3 & $15^{\mathrm{a}}$ & 2 & $14^{\mathrm{b}}$ & 4 & $14^{\mathrm{b}}$ & 3 \\
\hline \multicolumn{13}{|l|}{ Foods (g/10 MJ) } \\
\hline Vegetables & 155 & 105 & 171 & 144 & 139 & 137 & $179^{\mathrm{a}}$ & 132 & $178^{\mathrm{a}}$ & 171 & $131^{\mathrm{b}}$ & 112 \\
\hline Fruit & 200 & 209 & 164 & 246 & 164 & 188 & $244^{\mathrm{a}}$ & 190 & $159^{b}$ & 186 & $177^{\mathrm{b}}$ & 161 \\
\hline Fish & $12^{\mathrm{a}}$ & 20 & $14^{\mathrm{b}}$ & 43 & $15^{\mathrm{a}}$ & 32 & $12^{\mathrm{a}}$ & 21 & $11^{\mathrm{b}}$ & 32 & $12^{\mathrm{a}}$ & 24 \\
\hline Rye bread & $67^{\mathrm{a}}$ & 61 & $53^{\mathrm{b}}$ & 67 & $46^{\mathrm{b}}$ & 78 & $54^{\mathrm{a}}$ & 54 & $50^{a, b}$ & 67 & $36^{\mathrm{b}}$ & 44 \\
\hline White bread & $57^{\mathrm{b}}$ & 53 & $45^{\mathrm{c}}$ & 56 & $79^{\mathrm{a}}$ & 66 & $71^{\mathrm{b}}$ & 63 & $76^{\mathrm{b}}$ & 89 & $88^{a}$ & 66 \\
\hline Butter on bread & 8 & 13 & 8 & 15 & 10 & 15 & 8 & 10 & 8 & 13 & 9 & 10 \\
\hline Full-fat cheese & $4^{a}$ & 10 & $3^{a, b}$ & 10 & $7^{\mathrm{a}}$ & 16 & 3 & 6 & 4 & 11 & 4 & 13 \\
\hline French fried potatoes & $22^{\mathrm{a}}$ & 32 & $22^{\mathrm{b}}$ & 55 & $27^{\mathrm{a}, \mathrm{b}}$ & 47 & $19^{\mathrm{a}}$ & 33 & $32^{\mathrm{a}}$ & 79 & $23^{a}$ & 42 \\
\hline Sausages & $8^{\mathrm{a}}$ & 22 & $6^{b}$ & 26 & $4^{a, b}$ & 15 & 6 & 22 & 6 & 36 & 5 & 25 \\
\hline Sweets \& chocolate & 18 & 23 & 40 & 56 & 26 & 32 & 25 & 31 & 37 & 54 & 34 & 39 \\
\hline Cakes \& biscuits & $31^{a}$ & 44 & $32^{\mathrm{b}}$ & 66 & $43^{a}$ & 74 & $36^{\mathrm{b}}$ & 44 & $29^{c}$ & 55 & $61^{\mathrm{a}}$ & 71 \\
\hline SSB & $254^{\mathrm{b}}$ & 302 & $422^{a, b}$ & 488 & $409^{\mathrm{a}}$ & 352 & $224^{\mathrm{b}}$ & 231 & $343^{a, b}$ & 400 & $351^{a}$ & 367 \\
\hline \multicolumn{13}{|l|}{ Energy density (kJ/100 g) } \\
\hline Energy density, foods & $775^{b}$ & 167 & $854^{\mathrm{a}}$ & 244 & $868^{\mathrm{a}}$ & 217 & $734^{b}$ & 165 & $840^{\mathrm{a}}$ & 236 & $864^{\mathrm{a}}$ & 236 \\
\hline Energy density, beverages & $95^{\mathrm{b}}$ & 54 & $104^{a, b}$ & 62 & $115^{\mathrm{a}}$ & 56 & $88^{\mathrm{c}}$ & 49 & $104^{\mathrm{b}}$ & 65 & $107^{\mathrm{a}}$ & 59 \\
\hline
\end{tabular}

$\mathrm{E} \%$, percentage of energy intake; SSB, sugar-sweetened beverages.

${ }_{a, b, c}$ For each gender group, mean values within a row with unlike superscript letters were significantly different $(P<0 \cdot 05)$.

dietary quality in children ${ }^{(24)}$. Moreover, a high intake of energy-dense foods has been convincingly identified as a factor promoting weight gain ${ }^{(2)}$.

The majority of the children did not meet the dietary recommendations for added sugars, saturated fat, fish and fruit and vegetables on a weekly basis. The present results therefore further emphasize the importance of considering the unfavourable dietary intake patterns during weekends and Fridays.

To the authors' knowledge, the present study is the first on the diet quality on weekdays $v$. weekend days in a representative sample of children in Europe. Although few studies have addressed this issue specifically in school-aged children, similar findings for certain key variables such as SSB and the percentage of energy from fat have been presented previously ${ }^{(12,13)}$. The tendency towards less healthy dietary habits during weekends compared with weekdays is also in accordance with other studies in preschool children ${ }^{(25-27)}$. A Scottish study of 5 -17-year-olds showed no significant differences in energy intake, total fat, saturated fat and non-milk extrinsic sugars between weekdays and weekend days ${ }^{(28)}$; however, the overall findings suggested that the weekend is a period with less healthy dietary patterns compared with weekdays.

In the present study, the significantly higher energy intake on Fridays and weekend days compared with weekdays stresses that not only did the children have less healthy dietary habits on Fridays and weekend days, they also consumed more in total rather than compensating by eating less amounts of more regular foods. This is of concern in the prevention of overweight in children because these dietary habits may promote positive energy balance, thereby increasing the risk of becoming overweight and obese. Furthermore, the finding that especially sugar-rich foods and beverages contributed more to the energy intake on Fridays and weekend days compared with weekdays is of concern. Findings from epidemiological studies clearly indicate that regular consumption of SSB may lead to weight gain and substantially increase the risk of developing chronic diseases $^{(29)}$. In addition, a high intake of added sugars may increase the risk of a nutritionally inadequate diet ${ }^{(30)}$ and is found to be positively associated with multiple measures known to increase CVD risk in adolescents ${ }^{(31)}$.

Some general environmental and structural differences between schooldays and non-schooldays may in part explain the findings that the dietary quality is lower on weekend days. Schooldays may be more structured and supervised, while parents' attitudes towards healthy eating habits and the availability of different foods and beverages during weekends are most likely very important factors for the variation in dietary quality during the 
week $^{(9)}$. The perception that it is acceptable to lessen the restrictions during weekends on food groups that should be limited in the diet has been described in a combined qualitative and quantitative Danish study concerning parents' motives to give their children sugar-rich foods ${ }^{(32)}$. The interviewed parents expressed the view that they felt capable of controlling their children's sugar intake. However, the dietary intake data revealed that the children had a considerably higher intake of added sugars than recommended. The parents also expressed the view that it has become a tradition to give children sugar-rich foods during weekends and that a 'culture of cosiness' is seen as a legitimized cause for this. The promotion of healthy eating habits might benefit from more focus on changing this attitude.

Weekends also include a tendency for children to be less physically active than on weekdays and spend more time in sedentary behaviours, including television viewing and other screen time ${ }^{(33-35)}$, thereby further increasing the risk for weight gain during weekend days. Moreover, extended periods spent watching television has been associated with generally having less healthy food preferences and food habits in school-aged children ${ }^{(36)}$; thus these factors may act together in an undesirable direction.

In dietary assessment, Fridays are usually considered equal to other weekdays. However, results from the present study showed that the diet on Fridays appeared as a mix of the diet on weekdays and weekend days. Furthermore, according to the variables analysed in the present study, there were more significant differences between Fridays and weekdays than between Fridays and weekend days. This suggests that in assessment of dietary intake, the weekend is not necessarily limited to Saturdays and Sundays, but may include Fridays as well. The issue of whether dietary intake on Fridays should be considered as belonging to weekdays or weekend days needs to be addressed in future dietary assessment studies.

As for all dietary assessment studies, a limitation of the present study is that self-reported food recording may potentially be subject to misreporting. However, the degree of under-reporting seemed to be rather limited with the exception of the group of children aged 11-14 years, which is recognized as a particularly challenging age group when assessing dietary intake ${ }^{(37)}$. While parents take the full responsibility for the dietary recording of younger children, older children often record their intakes with less parental assistance. This is reasonable from the point of view that older children may have more frequent snacking outside the home and less structured eating patterns, which the parents may not know in detail. However, this combination also means that food items or eating occasions may be more prone to be forgotten or missed out by the older children. In addition, sensitivity to social desirability and possibly decreased interest in dietary recording may increase the susceptibility to underreporting among older children ${ }^{(37)}$.
Acknowledging that dietary under-reporting is a wellrecognized, ubiquitous concern in dietary assessment, we assessed the prevalence of under-reporters using the Goldberg method. Although this approach has some limitations in that it only identifies the most extreme misreporters and is considered to have a low specificity at the individual level ${ }^{(38)}$, it is the most commonly used approach when the doubly labelled water method or other objective measurements of energy expenditure are not available.

One strength of the present study is the separate analyses of data for the three age groups to allow for different eating patterns and different challenges in dietary assessment represented by the age span of 4-14 years. Another major strength is the comprehensive dietary data amassed from daily recordings of dietary intake for seven consecutive days by each participant. These data enabled detailed analyses of the diet quality across the week, including specific distinction of the diet on Fridays. Other strengths include the nationwide character of the study and the wide age span of the sample that render the results more generalizable to children in the general population.

\section{Conclusions}

Significant differences and distinct characteristic patterns were found in children's diet quality during weekdays, Fridays and weekend days. The present study suggests that in the prevention of childhood overweight and obesity, more attention should be paid to the higher energy intake, especially from sugar-rich foods and beverages, on Fridays and weekend days.

\section{Acknowledgements}

This work was supported by the university PhD scholarships under DTU Food, Technical University of Denmark. The authors declare no conflict of interest. B.W.R. designed the analyses of the present study, performed the statistical analyses and was responsible for writing the manuscript. J.M. was responsible for the design and collection of data in the Danish National Survey of Dietary Habits and Physical Activity. P.B.B. contributed with statistical counselling. B.W.R., C.H., J.M., P.B.B., L.F.A. and I.T. all participated in the discussion of the results and revision of the manuscript. The authors are grateful to researcher Anja Biltoft-Jensen, senior advisor Sisse Fagt and senior researcher Margit Velsing Groth, who are responsible for the design and development of questionnaires to the Danish National Survey of Dietary Habits and Physical Activity. The authors are also grateful to senior advisor Tue Christensen, dietitian Karin Hess Ygil, data scanning manager Hanne-Jette Hinch and data warehouse manager Karsten Kørup, for their contributions to the data processing. 


\section{References}

1. World Cancer Research Fund/American Institute for Cancer Research (2007) Food, Nutrition, Physical Activity, and the Prevention of Cancer: A Global Perspective. Washington, DC: AICR

2. World Health Organization (2003) Diet, Nutrition and the Prevention of Chronic Diseases. Joint WHO/FAO Expert Consultation. WHO Technical Report Series no. 916. Geneva: WHO.

3. Wang Y \& Lobstein T (2006) Worldwide trends in childhood overweight and obesity. Int J Pediatr Obes 1, 11-25.

4. Berenson GS (2012) Health consequences of obesity. Pediatr Blood Cancer 58, 117-121.

5. Wright CM, Emmett PM, Ness AR et al. (2010) Tracking of obesity and body fatness through mid-childhood. Arch Dis Child 95, 612-617.

6. Patterson E, Warnberg J, Kearney J et al. (2009) The tracking of dietary intakes of children and adolescents in Sweden over six years: the European Youth Heart Study. Int J Behav Nutr Phys Act 6, 91.

7. Elmadfa I, Meyer A, Nowak V et al. (2009) European Nutrition and Health Report 2009. Ann Nutr Metab 55, Suppl. 2, 1-40.

8. Pedersen A, Fagt S, Groth M et al. (2010) Danskernes kostvaner 2003-2008. Hovedresultater (Dietary Habits in Denmark 2003-2008. Main Results). Copenhagen: National Food Institute, Technical University of Denmark.

9. Taylor JP, Evers S \& McKenna M (2005) Determinants of healthy eating in children and youth. Can J Public Health 96, Suppl. 3, S20-S29.

10. von Hippel PT, Powell B, Downey DB et al. (2007) The effect of school on overweight in childhood: gain in body mass index during the school year and during summer vacation. Am J Public Health 97, 696-702.

11. Yanovski JA, Yanovski SZ, Sovik KN et al. (2000) A prospective study of holiday weight gain. $N$ Engl J Med 342, 861-867.

12. Bjelland M, Lien N, Grydeland M et al. (2011) Intakes and perceived home availability of sugar-sweetened beverages, fruit and vegetables as reported by mothers, fathers and adolescents in the HEIA (HEalth In Adolescents) study. Public Health Nutr (Epublication ahead of print version).

13. Cullen KW, Lara KM \& de Moor C (2002) Children's dietary fat intake and fat practices vary by meal and day. J Am Diet Assoc 102, 1773-1778.

14. Rothausen BW, Matthiessen J, Groth MV et al. (2012) Comparison of estimated energy intake from $2 \times 24$-hour recalls and a seven-day food record with objective measurements of energy expenditure in children. Food Nutr Res (Epublication ahead of print version).

15. Biltoft-Jensen A, Matthiessen J, Rasmussen LB et al. (2009) Validation of the Danish 7-day pre-coded food diary among adults: energy intake $\mathrm{v}$. energy expenditure and recording length. Br J Nutr 102, 1838-1846.

16. Sepp H, Ekelund U \& Becker W (2004) Enkätfrågor om kost och fysisk aktivitet bland vuxna. Underlag till urval av frågor $i$ befolkningsinriktade enkäter (Survey Questions about Diet and Physical Activity among Adults - The Basis for Selection of Questions in Population-based Surveys). Uppsala: Livsmedelsverket.

17. Fagt S, Andersen LF, Anderssen SA et al. (2009) Nordic Monitoring on Diet, Physical Activity and Overweight: Part 1: Description of a Common Nordic Method for Collecting Representative Data. Copenhagen: National Food Institute, Technical University of Denmark.

18. Nordic Council of Ministers (2004) Nordic Nutrition Recommendations 2004. Integrating Nutrition and Physical Activity. Nord 2004:13, 4th ed. Copenhagen: Nordic Council of Ministers.
19. Astrup AV, Andersen NL, Stender S et al. (2005) Kostrådene 2005 (The Danish Dietary Recommendations 2005). Copenhagen: Danish Institute for Food and Veterinary Research and Danish Nutrition Council.

20. Cole TJ, Bellizzi MC, Flegal KM et al. (2000) Establishing a standard definition for child overweight and obesity worldwide: international survey. BMJ 320, 1240-1243.

21. Goldberg GR, Black AE, Jebb SA et al. (1991) Critical evaluation of energy intake data using fundamental principles of energy physiology: 1 . Derivation of cut-off limits to identify under-recording. Eur J Clin Nutr 45, 569-581.

22. Torun B, Davies PS, Livingstone MB et al. (1996) Energy requirements and dietary energy recommendations for children and adolescents 1 to 18 years old. Eur J Clin Nutr 50, Suppl. 1, S37-S80.

23. Food and Agriculture Organization of the United Nations/ World Health Organization/United Nations University (1985) Energy and Protein Requirements. Joint FAO/ WHO/UNU Expert Consultation. WHO Technical Report Series no. 724. Geneva: WHO.

24. Patterson E, Warnberg J, Poortvliet E et al. (2010) Dietary energy density as a marker of dietary quality in Swedish children and adolescents: the European Youth Heart Study. Eur J Clin Nutr 64, 356-363.

25. Sepp H, Lennernas M, Pettersson R et al. (2001) Children's nutrient intake at preschool and at home. Acta Paediatr $\mathbf{9 0}$, 483-491.

26. Garemo M, Lenner RA \& Strandvik B (2007) Swedish preschool children eat too much junk food and sucrose. Acta Paediatr 96, 266-272.

27. Lehtisalo J, Erkkola M, Tapanainen H et al. (2010) Food consumption and nutrient intake in day care and at home in 3-year-old Finnish children. Public Health Nutr 13, 957-964.

28. Macdiarmid J, Loe J, Craig LC et al. (2009) Meal and snacking patterns of school-aged children in Scotland. Eur J Clin Nutr 63, 1297-1304.

29. Hu FB \& Malik VS (2010) Sugar-sweetened beverages and risk of obesity and type 2 diabetes: epidemiologic evidence. Physiol Behav 100, 47-54.

30. Mølgaard C, Andersen NL, Barkholt V et al. (2003) Sukkers sundhedsmæssige betydning (The impact of sugar on health). Danish Med Bull 165, 4207-4210.

31. Welsh JA, Sharma A, Cunningham SA et al. (2011) Consumption of added sugars and indicators of cardiovascular disease risk among US adolescents. Circulation 123, 249-257.

32. Iversen JD, Matthiessen J, Fagt S et al. (2011) Børns sukkervaner. Undersøgelse af sukkerkulturen blandt børnefamilier med 4-12-årige børn (Children's Sugar Habits - A Study of the Sugar Culture Among Families with 4-12-year-old Children). Copenhagen: National Food Institute, Technical University of Denmark.

33. Rey-Lopez JP, Vicente-Rodriguez G, Ortega FB et al. (2010) Sedentary patterns and media availability in European adolescents: the HELENA study. Prev Med 51, 50-55.

34. Rowlands AV, Pilgrim EL \& Eston RG (2008) Patterns of habitual activity across weekdays and weekend days in 9-11-year-old children. Prev Med 46, 317-324.

35. Soric M \& Misigoj-Durakovic M (2010) Physical activity levels and estimated energy expenditure in overweight and normalweight 11-year-old children. Acta Paediatr 99, 244-250.

36. Hare-Bruun H, Nielsen BM, Kristensen PL et al. (2011) Television viewing, food preferences, and food habits among children: a prospective epidemiological study. $B M C$ Public Health 11, 311.

37. Livingstone MB, Robson PJ \& Wallace JM (2004) Issues in dietary intake assessment of children and adolescents. BrJ Nutr 92, Suppl. 2, S213-S222.

38. Black AE (2000) The sensitivity and specificity of the Goldberg cut-off for EI:BMR for identifying diet reports of poor validity. Eur J Clin Nutr 54, 395-404. 